Measuring in action research:

Four ways of integrating quantitative methods in participatory dynamics

\author{
Joel Martí \\ Centre d'Estudis Sociològics sobre la Vida Quotidiana i el Treball (QUIT) \\ Institut d'Estudis del Treball (IET) \\ Department of Sociology \\ Universitat Autònoma de Barcelona \\ e-mail: Joel.Marti@uab.cat
}

The final version of this paper has been published in Action Research by Sage Pub.:

Martí, J. (2015). Measuring in action research: Four ways of integrating quantitative methods in participatory dynamics. Action Research. Advance online publication. Available at http://dx.doi.org/10.1177/1476750315590883. 


\title{
Measuring in action research: Four ways of integrating quantitative methods in participatory dynamics
}

\begin{abstract}
Although action research uses both qualitative and quantitative methods, few contributions have addressed the specific role of the latter in this kind of research. This paper focuses on how quantitative methods can be integrated with participatory dynamics in action research designs. Four types of integration are defined and exemplified. The paper concludes with some reflections on how the integration of quantitative methods in these designs must address epistemological and methodological issues.
\end{abstract}

\section{Keywords}

Action research, participatory research, quantitative methods, participatory surveys, mixed methods

Quantitative researchers and action researchers often come from different academic communities, hold different methodological competences, and conceive research differently. Although some years ago, action researchers called for the use of quantitative methods in action research (AR) (Greenwood \& Levin, 1998; Chandler \& Torbert, 2003), there has been little interweaving of these two communities and few methodological discussions on this topic. This paper addresses this issue by presenting the mixed-methods nature of action research and by introducing and exemplifying different ways of integrating quantitative methods in the participatory dynamics of AR.

Although AR is often associated with (a kind of) qualitative research, there are at least two main reasons for differentiating between these approaches. The first one is epistemological: an emphasis on coproduction of knowledge and on the performative dimension (which implies participating, learning, making decisions and acting) (Reason \& Bradbury, 2001) places AR in a different framework in relation to other ways of knowing focused on hearing and understanding meanings by an external researcher, as in qualitative research. The second reason for differentiating between $A R$ and qualitative research is methodological: AR is grounded not only in qualitative methods but also in quantitative and mixed methods (Chandler \& Torbert, 2003; Creswell, 2002; Greenwood \& Levin, 1998; Ivankova, 2014, Mertens, 2007; Torbert, 2000) ${ }^{1}$. Actually,

${ }^{1}$ As Greenwood and Levin (1998) state, the misconception of associating AR with qualitative methods "probably arises from the belief that action-oriented work cannot be scientific (precisely because it involves action) and the additional assumption 
the tools that specifically characterize AR are neither quantitative nor qualitative, at least in a "conventional" way, but have a strong performative component: assisting persons or groups, networking, promoting and planning actions are, ultimately, strategies aimed at helping participants to engage in the production of knowledge and to address practical challenges. Thus, the starting point of this paper is the methodological distinction between quantitative, qualitative and AR approaches, and between the prime methods that characterize these approaches: (a) surveys and statistical analyses for gathering and analyzing quantitative data about the world (QUAN); (b) qualitative interviews, participant observation and discourse analysis for understanding meanings from the actor's point of view (QUAL); (c) actions, meetings and workshops with a performative component for addressing change (PART). ${ }^{2}$

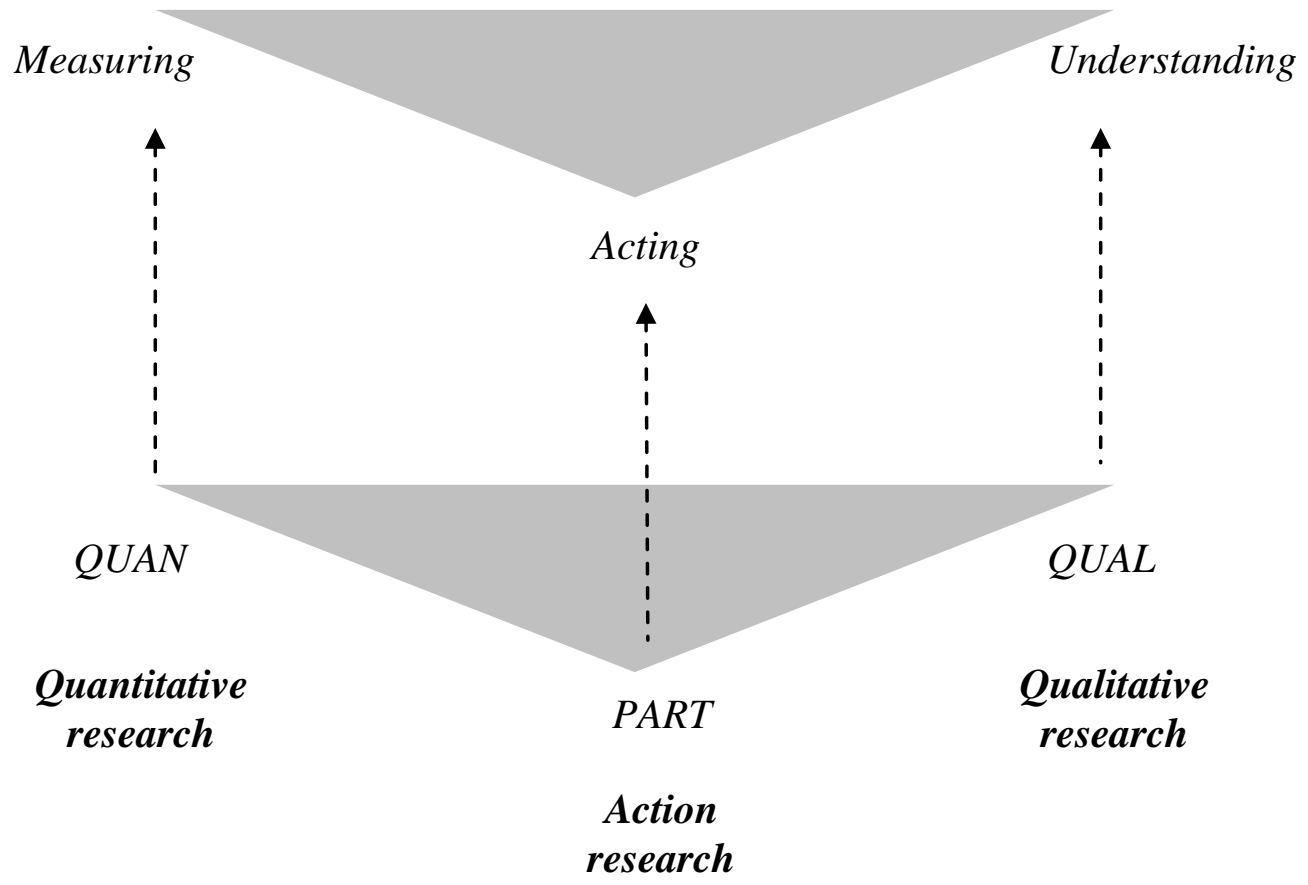

Figure 1. Methodological approaches, methods and aims. Baseline (and simple) model

Although single method designs may maintain the strict correspondence between methods and approaches, the practice of integrating different methods in a research design is not new, and a wide methodological corpus on mixed methods has been consolidated in recent years (among others, Creswell and Plano Clark, 2007; Tashakkori and Teddlie, 2003). The main debates within the mixed methods literature have been

(erroneous in our view) that quantitative research must be more scientific than qualitative research" (pp. 6-7).

${ }^{2}$ Of course, methods like surveys, interviews and focus groups are also social actions, but the focus of participatory methods is in the action itself. 
focused on "conventional research" (aimed at describing, understanding and explaining social realities) and on the relation between QUAN-QUAL methods. In contrast, contributions that address mixed methods designs in AR are still scarce (but see Mertens, Bledsoe, Sullivan, \& Wilson, 2010; Ivankova, 2014) and do not systematize how qualitative and quantitative methods are integrated with participatory dynamics.

Use of qualitative methods is the most common form of integrating conventional research methods in AR. In fact, the emphasis of AR on "hearing voices" of participants makes these methods close to this approach. However, measuring is often needed to support social action on knowledge about how things are distributed, and the use of quantitative methods is not rare: in their review of AR designs in nursing and social work, Munn-Giddings, McVicar, and Smith (2008) and McVicar, Munn-Giddings, and Abu-Helil (2012) found that although the balance was strongly in favor of qualitative methods, a total of 38 applications of quantitative methods were used within 62 nursing studies reviewed (questionnaires being the most commonly used tool), and 13 questionnaires were applied within 24 social work studies.

Thus, the question is not whether quantitative methods can be used in AR (as they have already long been so used) but rather whether there are reasons that these methods should not be used. The key issue here is the possible ontological and epistemological incompatibility between quantitative and AR approaches. In his historical review on the use of numbers in science and public life, Porter (1995) states that the development of quantification in the modern word must be understood as a "technology of distance" under which judgments appear to be neutral and aseptic. But Porter, as well as Fioramonti (2014) in a more recent work, shows that quantification, far from being a neutral practice, has long been used as a means to objectify life in certain ways and to shape and regulate social practices. Because quantitative data, like all data, show certain aspects of reality while dismissing others (Wright, 2014), what would be problematic in AR -and in other types of research- would be considering data as preexisting and neutral. The recognition of the constructed and performative dimensions of measuring allows its integration in research processes where actors are engaged in producing knowledge from their social positions and goals, and in enacting social realities (Law \& Urry, 2004). Thus, the issue to address is how quantitative methods can help to improve this knowledge and these realities.

From this point, the aim of this article is to present how these methods may be integrated in research designs that focus on a performative dimension and that, at some stage, need measuring. ${ }^{3}$

First, I will define a typology of four different ways of integrating quantitative methods in AR designs. Second, I will present some examples of different applications of each type of integration previously defined. Finally, I will conclude with some

\footnotetext{
${ }^{3}$ Although it is not the attempt of this paper, participatory tools can also be integrated in conventional research with the aim of improving its quality and promoting the use of research findings at the local level (Torrance, 2012), or when doing academic research about AR (see Zuber-Skerritt \& Fletcher, 2007).
} 
reflections on how the integration of these methods in AR projects must address epistemological and methodological issues that arise when applying these methods.

\section{A typology for integrating quantitative methods in participatory dynamics}

This section presents a typology of AR designs that integrate quantitative methods in different ways. Because it is not the aim of this paper to address quantitative-qualitative relations in $A R$, but rather the integration of quantitative methods (QUAN) in participatory dynamics (PART), the specific focus will be on the relation between QUAN and PART.

By adapting some of the terminology and notation criteria developed in the field of mixed methods (Creswell \& Plano Clark, 2007; Morse, 2003; Teddlie \& Tashakkori, 2009), a main distinction can be made between two different types of integration regarding whether PART and QUAN are conceived as distinct phases of an AR process (sequential integration) or as joined, inseparable tools (embedded integration).

Sequential integration refers to those situations where one method precedes another, which is designed following the results of the first. As in "conventional" mixed methods designs, the sequence can go in both directions: QUAN $\rightarrow$ PART or PART $\rightarrow$ QUAN. In the former, the participatory phase benefits from the data gathered in the quantitative phase, which may result in improving participant selection or identifying topics for discussion. In the latter, the quantitative phase can be used to measure the outputs or the outcomes of an AR project or to monitor issues defined in a participatory phase.

In the case of embedded integration, quantitative tools and participatory tools are not only dependent but also nested; i.e., part of the same method. ${ }^{4}$ In this scenario, methodological integration occurs not between methods but within one method (Ibáñez 1992, p. 67), and participants are fully implicated in the quantitative dimension. Embedding can also occur in two ways: (a) a participatory tool that integrates within it a quantitative component with the aim of measuring some issues related to participation (PART[quan]); (b) a quantitative tool that integrates participatory dynamics in at least one stage of its development (QUAN[part]). In the QUAN[part] designs, participants become involved in the development of the quantitative method, and thus, the method aims not only to measure but also to address in some way a performative action. This is possibly the most challenging design for conventional quantitative methods, as validity and reliability issues may arise when considering the intervention of participants. I will return to this topic in conclusions.

As shown in Table 1, these diverse forms of integration are situated in different stages of the AR cycle and result in a different role by participants in the implementation of quantitative methods.

\footnotetext{
${ }^{4}$ I adopt here a more restricted notion of "embedding" than Creswell and Plano Clark (2007), in the sense that the embedded tool is completely within (joint with) the main method.
} 
Table 1. Four ways of integrating quantitative methods in participatory dynamics of action research

\begin{tabular}{|c|c|c|c|c|}
\hline & \multicolumn{2}{|c|}{ Sequential integration } & \multicolumn{2}{|c|}{ Embedded integration } \\
\hline & QUAN $\rightarrow$ PART & $\mathrm{PART} \rightarrow \mathrm{QUAN}$ & PART[quan] & QUAN[part] \\
\hline $\begin{array}{l}\text { Goals of } \\
\text { QUAN within } \\
\text { AR process }\end{array}$ & $\begin{array}{l}\text { Improve } \\
\text { reflection with } \\
\text { evidence-based } \\
\text { data }\end{array}$ & $\begin{array}{l}\text { Monitor } \\
\text { changes and } \\
\text { provide } \\
\text { relevant data } \\
\text { for evaluation }\end{array}$ & $\begin{array}{l}\text { Improve } \\
\text { deliberation } \\
\text { and decision } \\
\text { making }\end{array}$ & $\begin{array}{l}\text { Improve } \\
\text { observation; } \\
\text { engage } \\
\text { participants in } \\
\text { the process }\end{array}$ \\
\hline $\begin{array}{ll}\text { Role } & \text { of } \\
\text { participants in } \\
\text { QUAN }\end{array}$ & $\begin{array}{l}\text { Data } \\
\text { receivers }\end{array}$ & $\begin{array}{l}\text { Data } \\
\text { receivers }\end{array}$ & $\begin{array}{l}\text { Data } \\
\text { producers }\end{array}$ & $\begin{array}{l}\text { Data } \\
\text { producers }\end{array}$ \\
\hline AR cycle & Observe $\rightarrow$ Reflect & Act $\rightarrow$ Observe & Reflect, Plan & Observe, Act \\
\hline
\end{tabular}

Of course, reality is more complex than these four prototypes, and the iterative nature of AR can lead to designs that may intersect or combine two or more of them.

\section{Applications}

In this section, some applications of these four types of integration are described. Although the review is not exhaustive, it shows that a variety of quantitative procedures can be integrated in AR projects, such as extant statistical data, random sampling, surveys, direct observation or social network analysis.

\section{Type I. Sequential integration $Q U A N \rightarrow P A R T:$ From measure to participation}

Possibly the most obvious way of integrating quantitative data in an AR project is to begin with an analysis of extant statistical sources as a way to contextualize the topic of the research and to justify the need for intervention. However, in other projects, a first quantitative phase relies on primary data.

The research developed by Dabaieh (2013) is a typical example of a sequential design in which quantitative methods relying on primary data precede the participatory/action phase with the aim of helping its design. The goal of the project was to help to prevent loss of knowledge about desert vernacular architecture and to encourage vernacular know-how to become a living part of future building practices in Balat, a small town of the Western Desert of Egypt. The project was divided into three phases. During the first phase, a questionnaire about satisfaction with current vernacular houses and willingness to live in mud brick houses in the future was administered to a stratified random sample of 60 of Balat's inhabitants. Dabaieh also gathered historical data and conducted qualitative interviews. From questionnaires and interviews with 
locals, she concluded that they suffered from a lack of facilities in their homes, alongside safety issues due to deterioration of neighboring deserted houses within the town. Based on the results of this first stage, a participatory phase was designed. A first seminar was organized with the participation of dwellers, local investors and small business owners together with the local non-governmental organization (NGO) representatives, engineers, contractors and craftsmen to discuss these issues. A second seminar was then planned with the aim to design a desert vernacular model house. The third and last phase of the project was the implementation of the building phase in collaboration with locals.

Shuayb (2014) used an appreciative inquiry approach for developing school effectiveness and care in three secondary schools in a deprived district in the south of Lebanon. Her design followed a schema QUAN $\rightarrow$ QUAL $\rightarrow$ PART and thus shows how the three methods can be sequentially integrated within an AR design. In the first phase (QUAN), Shuayb surveyed 180 students using a questionnaire with several open-ended questions followed by 80 Likert-type statements about teaching and learning, school environment, discipline policies, and students' relationships with their peers and teachers. She also surveyed teachers to identify the characteristics of the teacher/student relationships, teacher/school relationship, teaching practices, democracy in the school, staff relationships, and class management. This quantitative phase allowed the researcher to identify the positive experiences in the schools in a short period without interrupting the school's schedule. In the second phase (QUAL), the results of both surveys were shared during focus groups with students and qualitative interviews with teachers; this phase allowed the validation of quantitative results and was also aimed at identifying the needs of the different groups. The third phase (PART) included the training of students to conduct appreciative inquiry interviews, fieldwork, and a final planning workshop aimed at developing proposals for improving school organization based on information gathered in the previous phases.

Another example of sequential integration was developed by Kothari, Hamel, MacDonald, Meyer, Cohen, and Bonnenfant (2014). These authors used quantitative social network analysis to facilitate a reflective stance among Canadian public health practitioners involved in community networks and to help to strengthen collaborations with other community partners. First, participants completed an online egocentric network questionnaire focused on one of the many professional advocacy-oriented networks with which they might have been engaged. Quantitative data was gathered about practitioners' characteristics, their contacts and the relationships between them. Resulting sociograms and summary statistics of the networks were sent to participants for further discussion in a workshop. The focus of this discussion was on social network mapping and policy change:

The first author facilitated the discussion by encouraging participants to consider their current network, to comment on its potential effectiveness for advocacy activities and then to speculate about who might be missing from their network. Thus, the sociograms and associated measures served as tools for critical selfreflection of their community collaboration. (Kothari et al., 2014, p. 27). 


\section{Type II. Sequential integration $P A R T \rightarrow Q U A N \because:$ From participation to measuring}

A second type of integration of quantitative and participatory tools is when quantitative methods are applied after the participatory phase. This design can serve different objectives, such as evaluating an AR project or monitoring changes in the local setting.

Actually, designs that plan a posttest aimed at measuring change often include a pretest conducted before the participatory/action phase, sometimes applying quasiexperimental or experimental designs with control groups (see the review of community-based participatory research projects in the field of health conducted by Viswanathan et al., 2004).

An example of pre-post test design with a control group is a study by Russell, Walsh, Scott, and McIntosh (2014). These authors used problem-solving workshops to change the way that water birth practice was promoted and organized on a labor ward of an English obstetric-led hospital. A survey addressed to midwives allowed the authors to compare between pre- and postworkshop practices and between midwives who attended workshops and those who did not. The findings allowed causal claims about the effect of the problem-solving workshop on water birth practices.

Social network analysis also has been claimed to be relevant for AR insofar as transforming relations is often an aim of these projects (see, for instance, Ennis \& West, 2010; Martín, 1999; Villasante \& Martín, 2007; see also the review of Valente, 2012, on 'network interventions'). Following this method, Ennis and West (2013) analyzed changes in a community network before and after a community development project. This network was formed by citizens of a suburban neighborhood in Darwin (Australia) as a result of long-term issues concerning the social segregation of Aboriginals and nonAboriginals. A network analysis was used to observe changes in active participants' networks at the beginning and end of the project. Thorough a snowball sampling, they gathered data about relationships and measured the structure and composition of the network. Comparing pre- and postproject networks, they observed a postproject network that was larger and more cohesive, with more bridges and more cultural diversity.

\section{Type III. Embedded integration PART[quan]: Measuring within participatory tools}

In this type of integration, a quantitative tool is embedded within a participatory tool and is a constitutive part of its development.

In this design, measurement is often the end point of a participatory moment and helps a group to prioritize the results of discussion thorough voting, ranking or surveying participants in order to measure their options, opinions or decisions after deliberation. Although voting in its simplest form implies a count of individual choices, some procedures allow participants to distribute and weight their preferences on one or more options (as in nominal groups, see Delbecq, Van de Ven, \& Gustafson, 1975) or to do pairwise comparisons between a list of options and a set of criteria in order to identify the preferred option (prioritization matrices) (Tague, 2005, pp. 408-420). In the field of citizen participation, some variations of citizens' juries, like the German model of 'planning cells' (Dienel \& Harms, 2000), conclude discussions with a survey of 
participants about the topics that have been discussed during the preceding deliberative sessions.

In other participatory tools, quantitative methods are used to diagnose or analyze processes or ongoing ideas during debates with the aim of helping/improving further deliberation. For instance, in the field of French strategic prospective (see Godet, 2000), participant workshops include systematic analysis of scenarios, causal factors, actor strategies and action proposals aided by quantitative procedures that allow participants to weigh the effect of each element in the predicted outcome.

In the field of social network analysis, some software developments allow performance of participatory analyses of networks aided by algorithms of graph theory and social networks. Software programs like Vennmaker (Gamper, Schönhuth, \& Kronenwett, 2012) and Net-Map (Schiffer \& Hauck, 2010) facilitate process-oriented interviews or group meetings while constructing, visualizing and discussing a social network or a strategic actor mapping. As Schiffer and Hauck (2010) state, this type of strategy helps participants to analyze relations of cooperation, conflict and influence that go beyond the purely structure-driven approach of quantitative social network analysis but benefits from its algebra. These authors present a field study with a multistakeholder organization in northern Ghana with the aim of improving the coordination of actors toward sustainable use of water in the region. Network analysis, "helped board members use this knowledge strategically to push recommendations, developed by the board, to increase sustainable water governance" (Schiffer \& Hauck, 2010, p. 235).

A well-known tool that can also fit within this type of integration is the Delphi Method (Linstone \& Turoff 1975), based on anonymous interaction between participants as a mean of consensus building. Although participating for acting is not the aim of the original method, some contributions discuss the interweaving of Delphi Method with AR. Fraser (1999), in the context of an AR approach to curriculum improvement in a large multisited university in England, used Delphi as a tool among midwifery teachers to generate a list of priorities and actions for curriculum implementation and to identify ways in which staff development needs might be met more effectively. The author argues that this process, "enabled teachers to feel party to decision making rather than feeling solutions to problems were imposed by others. Sharing responses at all stages, culminating in whole team discussion and consensus or compromise meant that critical mass support was transparent" (Fraser, 1999, p. 499) and thereby contributed to team building.

Type IV. Embedded integration QUAN[part]: Participating and acting in quantitative methods

The previous section focused on how quantitative procedures can be integrated within participatory tools with the aim of improving or concluding discussions. In contrast, this section will focus on how the design, implementation and analysis of quantitative methods not only can address the main objective of measuring but also can promote participation and mobilization of involved persons and groups. 
Two main strategies can be distinguished in this type of integration: first, when participation involves a local group of actors whose members have an active role as coresearchers, while the studied population is analyzed as an "object" such as in a conventional quantitative design; and second, when the whole studied population participates in some way in the implementation of the method. These two strategies will now be discussed. In both cases, I will focus on surveys, as this is the most common quantitative method in which local actors participate. ${ }^{5}$

Regarding the first strategy, the participation of local actors engaged in the research process (as a local group of coresearchers) can be placed at different stages of the quantitative method (and often more than one): conception of the method, design, fieldwork, or analysis/interpretation. ${ }^{6}$

Examples of participatory survey applications (i.e., surveys that engage local actors at some stage of their development) include work by: Brown, Holtby, Zahnd, and Abbott (2005); Nussbaum, Hoover, Grossman, and Nussbaum (2004); Parrado, McQuiston, and Flippen (2005); Schulz, Parker, Israel, Becker, Maciak, and Hollis (1998); Travers et al. (2013); and Wright (2014).

Parrado et al. (2005) formed a local group of 14 community members who were involved in the stages of conceptualization, design, execution and interpretation of a survey about HIV risks among Hispanic migrants in Durham (USA). The local group contributed to conceptualizing the research problem and identifying issues to be addressed at the grant-writing stage. The authors state that this process "served the dual purpose of bringing locally specific information and context to the research design and also giving community members greater ownership of the investigative process" (Parrado et al., 2005, p. 212). Once funding was obtained, the group helped to design

${ }^{5}$ However, other applications can be found. For instance, Fontalvo-Herazo, Glaser and Lobato-Ribeiro (2007) showed how local stakeholders engaged with the definition of an indicator system as a tool for measuring changes and to influence local coastal management in Bragança (Brazil). Defoer, De Groote, Hilhorst, Kanté and Budelman (1998) assisted farmers of Noyaradougou (southern Mali) to draw a resource flow model aimed at diagnosing the way that they manage soil fertility; this information was transformed into management performance indicators and soil nutrient flows and partial balances, showing how quantitative analysis can improve learning and improve farming practices. Other tools for ranking and time trends analysis have been used in the framework of participatory rural appraisal (PRA) to address the difficulties found with conventional surveys in rural contexts and also as a tool for starting participatory processes (Chambers, 1994; Mayoux and Chambers 2005; see also Barahona and Levy, 2003, for an example of population census combining random sampling and PRA tools).

${ }^{6}$ Conversely, in some other cases, this participation may prevent the integration of quantitative methods in AR designs: "Residents of Madison County, for the Madison County study, stated a strong aversion toward surveys because of earlier experiences. Subsequently, the project adopted group interviews as a more acceptable method of data collection" (Viswanathan et al., 2004, p. 37). 
the questionnaire and gained access to a difficult-to-reach population. During fieldwork, its members conducted all interviews and also played an active role in collecting contextual information that assisted data interpretation.

Moving beyond the technical level, in other projects, the involvement of local actors is mainly at a political level and at the crucial decision stages of research, conceiving and driving the use of quantitative methods as a means to achieving their goals. Although this is not a common scenario (see Stoecker, 2009), an example is a case narrated by Wright (2014) in which an organization of small farmers in the Philippines conceived of a quantitative study to prove the validity of farmer-led sustainable agriculture compared with conventional techniques. Another application, described by Nussbaum et al. (2004), was an alliance of residents, physicians, scientists, and activists who designed, distributed, collected, and analyzed a health survey concerning people whose health had been at risk because of a plutonium production facility in Hanford (USA). Another example is the Trans PULSE project (Travers et al., 2013), in which a group of trans ${ }^{7}$ community members led a survey targeting a trans community in Ontario with the aim of identifying their problems and concerns regarding health and access to health services. This group selected research partners based on their ability to provide research-related expertise, their ability to be allies and their potential to let trans people to be experts on their own issues.

These examples show how participating within quantitative methods is not only limited to questionnaire design, data collection or dissemination of results, practices that remain at the "technical level," but also can involve controlling the overall research process (Travers et al., 2013) and provide empowerment by affording activists and affected populations valuable data in support of their political demands (Nussbaum et al., 2004, Schulz et al., 1998).

In a second strategy of QUAN[part] integration (where the whole studied population participates in some way in implementation of the method), we can place the method applied in a project conducted in a medium-sized town in the Barcelona metropolitan area described in Martí (2003). This method, which we called "household debate," was a survey targeting local households with school-age children (3-16 years), in the context of a wider project of local strategic planning. The tool addressed three main objectives: first, gathering quantitative data about everyday practices in the city and measuring public opinion about local issues; second, promoting an informed discussion among household members (including children) about local issues; and third, inviting citizens to engage more actively in the process. To achieve these aims, a notebook was designed by the research team with three content types: (a) information about the city obtained from secondary data and from a previous qualitative phase; (b) open-ended questions, asking for a written response in some of them, and pictures and maps in others; and (c) closed-ended questions as in a conventional questionnaire. While some of the questions asked for an individual response, others required brainstorming, and still others required debate and consensus among household members. The household

${ }^{7}$ A term that includes transsexual, transitioned, transgender, and genderqueer people, as well as some two-spirit people (Travers et al. 2013, p. 419). 
debates and the notebook completion were promoted indirectly by local schools (this also facilitated their involvement in the project) and directly by children, who brought the notebook home as one week of (voluntary) homework. Using this strategy, we reached a response rate of $29 \%$ of households (1043 households with a total of 2470 participants); notebook entries consisted of a discussion between two people in $31 \%$ of households, and between three or more people in $63 \%$ of households. Finally, almost $10 \%$ of participants declared an interest in participating more actively in the project and in workshops to be held in further phases of the process.

\section{Conclusions}

$\mathrm{AR}$ is a methodological approach focused on transformation of social reality. Thus, a performative dimension is a key feature of these designs, and participation by local actors in the research process is one of the main strategies. These designs commonly also address a quantitative dimension aimed at measuring social phenomena and a qualitative dimension aimed at understanding actors' perspectives as a means of providing participants with valid and rich data and facilitating their ability to develop successful action strategies. However, the specific contribution of quantitative methods to AR has long been ignored in the field (Chandler and Torbert, 2003, p. 148). With the goal of enriching AR literature, the aim of this paper has been to address specifically how quantitative methods can be integrated with participatory dynamics in AR designs.

The different types of integration that have been presented show that the simple model of Figure 1 can become more complex:
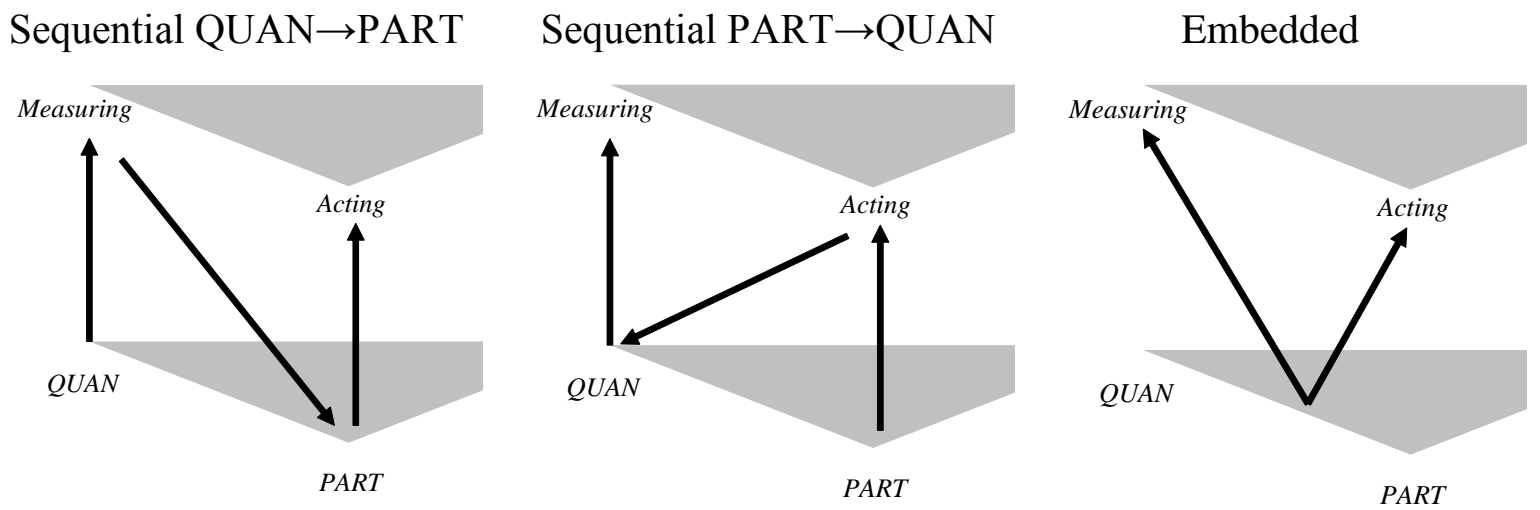

Figure 2. Models of integration QUAN-PART

Within AR designs, QUAN methods may acquire new forms that challenge the conventional way in which these methods are applied. Some final reflections can be made about this.

The first question refers to the relation between knowledge, power and social practice. As Wright (2014) states, there is a tendency in some quantitative research to 
leave these questions unproblematized or disconnected from the research process. Because data does not merely reflect an external world independent from actors/researchers and because selection of goals, research topics, definitions of categories, and statistical indicators are not neutral nor aseptic, integrating QUAN in AR means recognizing its constructed and performative characters and strategically addressing how measurement "helps to produce worlds" (Law \& Urry, 2004; Wright, 2014). Addressing this issue in particular AR settings also means dealing with conflicting relations and interests within the field, in which different actors (including professional researchers) may have unequal access to resources and divergent goals related to institutional pressures and politics that are not always visible (Schulz et al., 1998; Wing, 2002). In this sense, AR designs will have to deal with the different stakeholders who may have different goals and conceptualizations of what and how it should be measured.

The performative character of QUAN is even more challenging in the case of embedded integration, in which measuring and acting are conjoined in the same method, and thus, the participatory and performative nature of AR unfolds in the heart of QUAN. Conventional quantitative designs, which seek the maximum distance between the researcher and participants, traditionally ignore the performative effects on participants, or try to neutralize them if they are a potential source of bias. In contrast, in embedded integration, researchers do not ignore this issue but instead promote it strategically in the design. Thus, measuring is a means for improving discussion and decision making, and participation in quantitative methods is a means for improving measuring, but also learning, social debate and mobilization.

In some of these cases, threats to measurement quality may arise, such as selection bias or lack of randomization when samples are recruited by community members (Viswanathan et al., 2004) or response bias when interviewees are provided with information during survey implementation or are interviewed by their neighbors or members of the same organization (Pereda, Prada, \& Actis, 2003). Some strategies have been proposed to address these issues, such as designing respondent-driven samples (Heckathorn, 2002, cited in Travers et al., 2013), combining statistical sampling with participatory methods (Barahona \& Levy, 2003), providing information to interviewees after questionnaire completion (Pereda et al., 2003) or avoiding the interviewing of acquaintances to maintain confidentiality (Parrado et al., 2005).

Such strategies may improve the quality of QUAN methods within AR projects, as well as the overall quality of the AR process insofar as they successfully address key issues in AR quality such as democratic participation, catalytic validity and practical outcomes (Anderson, Herr, \& Nihlen; 1994; Champion \& Stowell, 2003; Heron, 1996; Kingsley \& Chapman, 2013; Martí \& Villasante, 2009; Reason, 2006).

\section{Acknowledgement}

The author would like to thank Davydd Greenwood for leading the review process of this article. 


\section{References}

Anderson G. L., Herr K., Nihlen, A. S. (1994). Studying your own school: an educator's guide to qualitative practitioner research. Thousand Oaks, CA: Sage.

Barahona, C., \& Levy, S. (2003). How to generate statistics and influence policy using participatory methods in research: reflections on work in Malawi 1999-2002 (Working Paper 2012). Brighton, England: Institute of Development Studies.

Brown, E. R., Holtby, S., Zahnd, E., \& Abbott, G. B. (2005). Community-based Participatory Research in the California Health Interview Survey. Preventing Chronic Disease, 2(4). Retrieved from http://www.cdc.gov/pcd/issues/2005/oct/05_0046.htm.

Chambers, R. (1994). Participatory rural appraisal (PRA): Analysis of experience. World development, 22(9), 1253-1268.

Champion, D., \& Stowell, F. (2003). Validating action research field studies: PEArL. Systemic Practice and Action Research, 16(1), 21-36.

Chandler, D., \& Torbert, B. (2003). Transforming inquiry and action interweaving 27 flavors of action research. Action Research, 1(2), 133-152.

Creswell, J. W. (2002). Educational research: Planning, conducting, and evaluating quantitative and qualitative research. Boston, MA: Pearson Education.

Creswell, J. W., \& Plano Clark, V. L. (2007). Designing and conducting mixed methods research. Thousand Oaks, CA: Sage.

Dabaieh, M. (2013). Participatory action research as a tool in solving desert vernacular architecture problems in the Western Desert of Egypt. Action Research, 11(3), 279-298.

Defoer, T., De Groote, H., Hilhorst, T., Kanté, S., \& Budelman, A. (1998). Participatory action research and quantitative analysis for nutrient management in southern Mali: a fruitful marriage? Agriculture, ecosystems \& environment, 71(1), 215228.

Delbecq, A. L., Van de Ven, A. H., \& Gustafson, D. H. (1975). Group techniques for program planning: A guide to nominal group and Delphi processes. Glenview, IL: Scott, Foresman \& Co.

Dienel, P. C., \& Harms, H. (2000). Repensar la democracia: Los núcleos de investigación participativa [Rethinking democracy: The Planning Cells] $(\mathrm{H}$. Harms, Trans.). Barcelona, Spain: El Serbal.

Ennis, G., \& West, D. (2010). Exploring the potential of social network analysis in asset-based community development practice and research. Australian Social Work, 63(4), 404-417.

Ennis, G., \& West, D. (2013). Using social network analysis in community development practice and research: a case study. Community Development Journal, 48(1), 40-57. 
Fioramonti, L. (2014). How numbers rule the world. The use and abuse of statistics in global politics. London: Zed Books.

Fontalvo-Herazo, M. L., Glaser, M., \& Lobato-Ribeiro, A. (2007). A method for the participatory design of an indicator system as a tool for local coastal management. Ocean \& Coastal Management, 50(10), 779-795.

Fraser, D. M. (1999). Delphi technique: one cycle of an action research project to improve the pre-registration midwifery curriculum. Nurse education today, 19(6), 495-501.

Gamper, M., Schönhuth, M., \& Kronenwett, M. (2012). Bringing qualitative and quantitative data together: Collecting network data with the help of the software tool VennMaker. In M. Safar, \& K. A. Mahdi (Eds.), Social Networking and Community Behavior Modeling: Qualitative and Quantitative Measures (pp. 193-213). Hershey, PA: IGI Global.

Godet, M. (2000). The art of scenarios and strategic planning: tools and pitfalls. Technological forecasting and social change, 65(1), 3-22.

Greenwood, D., \& Levin, M. (1998). Introduction to action research. Social research for social change. Thousand Oaks, CA: Sage.

Heron, J. (1996). Quality as primacy of the practical. Qualitative Inquiry, 2(1), 41-56.

Ibáñez, J. (1992). Perspectivas de la investigación social: El diseño en las tres perspectivas [Social research perspectives: Research design in three perspectives]. In M. García Ferrando, J. Ibáñez, \& F. Alvira (Eds), El análisis de la realidad social [The analysis of social reality] (3th ed., pp. 49-83). Madrid, Spain: Alianza Editorial.

Ivankova, N. V. (2014). Mixed Methods Applications in Action Research: From Methods to Community Action. Thousand Oaks, CA: SAGE

Kingsley, B. C., \& Chapman, S. A. (2013). Questioning the Meaningfulness of Rigour in Community-Based Research: Navigating a Dilemma. International Journal of Qualitative Methods, 12, 551-569.

Kothari, A., Hamel, N., MacDonald, J. A., Meyer, M., Cohen, B., \& Bonnenfant, D. (2014). Exploring community collaborations: social network analysis as a reflective tool for public health. Systemic Practice and Action Research, 27(2), 123-137.

Law, J. \& Urry, J. (2004). Enacting the social. Economy and Society, 33(3), 390-410.

Linstone, H. A., \& Turoff, M. (Eds.). (1975). The Delphi method: Techniques and applications (Vol. 29). Reading, MA: Addison-Wesley.

Martí, J. (2003, April). La integració metodològica en la investigació acció: el quadern de debat [Methodological integration in action research. The case of 'Household Debate']. Associació Catalana de Sociologia: IV Congrés Català de Sociologia, Reus, Spain. 
Martí, J., \& Villasante, T. R. (2009). Quality in action research: Reflections for secondorder inquiry. Systemic Practice and Action Research, 22(5), 383-396

Martín, P. (1999). El sociograma como instrumento que desvela la complejidad [The sociogram as a tool that reveals complexity]. Empiria, Revista de Metodología de Ciencias Sociales, 2, 129-151.

Mayoux, L., \& Chambers, R. (2005). Reversing the paradigm: quantification, participatory methods and pro-poor impact assessment. Journal of International Development, 17(2), 271-298.

McVicar, A., Munn-Giddings, C., \& Abu-Helil, C. (2012). Exploring the development of action research in nursing and social care in the UK: a comparative bibliometric review of action research designs in social work (2000-2010). Action Research, 10(1), 79-101.

Mertens, D. M. (2007). Transformative Paradigm Mixed Methods and Social Justice. Journal of Mixed Methods Research, 1(3), 212-225.

Mertens, D. M., Bledsoe, K., Sullivan, M., \& Wilson, A. (2010). Utilization of mixed methods for transformative purposes. In A. Tashakkori \& C. Teddlie (Eds.), Handbook of mixed methods in social and behavioral research (2nd ed., pp. 193-214). Thousand Oaks, CA: SAGE

Morse, J. M. (2003). Principles of mixed methods and multimethod research design. In A. Tashakkori \& C. Teddlie (Eds.), Handbook of mixed methods in social and behavorial research (pp. 189-208). Thousand Oaks, CA: Sage.

Munn-Giddings, C., McVicar, A., \& Smith, L. (2008). Systematic review of the uptake and design of action research in published nursing research, 2000-2005. Journal of Research in Nursing, 13(6), 465-477.

Nussbaum, R. H., Hoover, P. P., Grossman, C. M., \& Nussbaum, F. D. (2004). Community-based participatory health survey of Hanford, WA, downwinders: a model for citizen empowerment. Society and Natural Resources, 17(6), 547-559.

Parrado, E. A., McQuiston, C., \& Flippen, C. A. (2005). Participatory survey research integrating community collaboration and quantitative methods for the study of gender and HIV risks among Hispanic migrants. Sociological Methods \& Research, 34(2), 204-239.

Pereda, C., Prada, M., \& Actis, W. (2003, June). Investigación acción participativa: propuesta para un ejercicio activo de la ciudadanía [Participatory action research: proposal for an active exercise of citizenship]. Encuentro de la Consejería de Juventud. Córdoba, Spain.

Porter, T. (1995). Trust in numbers. The pursuit of objectivity in science and public life. Princeton, NJ: Princeton University Press.

Reason, P., \& Bradbury, H. (Eds.). (2001). Handbook of action research: Participative inquiry and practice. London: Sage Publications. 
Reason, P. (2006). Choice and quality in action research practice. Journal of Management Inquiry, 6(15), 187-203.

Russell, K., Walsh, D., Scott, I., \& McIntosh, T. (2014). Effecting change in midwives' waterbirth practice behaviours on labour ward: An action research study. Midwifery, 30(3), e96-e101.

Schiffer, E., \& Hauck, J. (2010). Net-Map: collecting social network data and facilitating network learning through participatory influence network mapping. Field Methods, 22(3), 231-249.

Schulz, A. J., Parker, E. A., Israel, B. A., Becker, A. B., Maciak, B. J., \& Hollis, R. (1998). Conducting a participatory community-based survey for a community health intervention on Detroit's east side. Journal of Public Health Management and Practice, 4(2), 10-24.

Shuayb, M. (2014). Appreciative Inquiry as a Method for Participatory Change in Secondary Schools in Lebanon. Journal of Mixed Methods Research, 8(3), 299307.

Stoecker, R. (2009). Are we talking the walk of community-based research? Action Research, 7(4), 385-404.

Tague, N. R. (2005). The Quality Toolbox. Milwaukee, WI: American Society for Quality.

Tashakkori, A. \& Teddlie, C. (Eds.), (2003). Handbook of mixed method research in the social and behavioral sciences. Thousand Oaks, CA: Sage.

Teddlie, C. \& Tashakkori, A. (2009). Foundations of mixed methods research. Integrating quantitative and qualitative approaches in the social and behavioral sciences. Thousand Oaks, CA: Sage.

Torbert, W. (2000). Transforming social science: Integrating quantitative, qualitative, and action research. In F. Sherman \& W. Torbert (Eds.), Transforming social inquiry, transforming social action (pp. 67-92). Boston, MA: Kluwer Academic Publishers.

Torrance, H. (2012). Triangulation, respondent validation, and democratic participation in mixed methods research. Journal of Mixed Methods Research, 6(2), 111-123.

Travers, R., Pyne, J., Bauer, G., Munro, L., Giambrone, B., Hammond, R., \& Scanlon, K. (2013). 'Community control' in CBPR: Challenges experienced and questions raised from the Trans PULSE project. Action Research, 11(4), 403422.

Valente, T. W. (2012). Network interventions. Science, 337, 49-53.

Villasante, T. R., \& Martín, P. (2007). Redes y conjuntos de acción: para aplicaciones estratégicas en los tiempos de la complejidad social [Networks and action groups: strategic applications in times of social complexity]. Política y sociedad, 44(1), 125-140. 
Viswanathan, M., Ammerman, A., Eng, E., Garlehner, G., Lohr, K. N., Griffith, D., ... \& Whitener, L. (2004). Community-based participatory research: Assessing the evidence. Evidence Report/Technology Assessment, 99, AHRQ Publication 04E022-2. Rockville, MD: Agency for Healthcare Research and Quality.

Wing, S. (2002). Social responsibility and research ethics in community-driven studies of industrialized hog production. Environmental Health Perspectives, 110(5), 437-444.

Wright, S. (2014). Quantitative Research Performing other Worlds: lessons from sustainable agriculture in the Philippines. Australian Geographer, 45(1), 1-18.

Zuber-Skerritt, O., \& Fletcher, M. (2007). The quality of an action research thesis in the social sciences. Quality Assurance in Education, 15(4), 413-436. 